\title{
Article \\ Study on the Agricultural Air Pollution Aggravated by the Rural Labor Migration
}

\author{
Ying Liu ${ }^{1}$, Shibing You ${ }^{1, *}$, Nan Li $^{2}$, Junsheng Fang ${ }^{1}{ }^{(}$, , Jie Jia ${ }^{1}$, Xuesong $\mathrm{Li}^{1, *}$ and Jingru Ren ${ }^{3}$ \\ 1 School of Economics and Management, Wuhan University, Wuhan 430072, China; \\ YingLiuYL@whu.edu.cn (Y.L.); jasonfang@whu.edu.cn (J.F.); jiejia@whu.edu.cn (J.J.) \\ 2 China Bohai Bank Co., Ltd., Tianjin 300012, China; nan05.li@cbhb.com.cn \\ 3 Shenzhen Institute of Information Technology, Shenzhen 518172, China; 2019000218@sziit.edu.cn \\ * Correspondence: sbyou@whu.edu.cn (S.Y.); xsli@whu.edu.cn (X.L.)
}

Citation: Liu, Y.; You, S.; Li, N.; Fang, J.; Jia, J.; Li, X.; Ren, J. Study on the Agricultural Air Pollution Aggravated by the Rural Labor Migration. Atmosphere 2022, 13, 174. https://doi.org/10.3390/ atmos13020174

Academic Editors: Zengyun Hu, Xuguang Tang and Qinchuan Xin

Received: 30 December 2021

Accepted: 20 January 2022

Published: 21 January 2022

Publisher's Note: MDPI stays neutral with regard to jurisdictional claims in published maps and institutional affiliations.

Copyright: (C) 2022 by the authors. Licensee MDPI, Basel, Switzerland. This article is an open access article distributed under the terms and conditions of the Creative Commons Attribution (CC BY) license (https:// creativecommons.org/licenses/by/ $4.0 /)$.

\begin{abstract}
In recent years, air pollution has received serious concerns from researchers, media, and the public sectors, but air pollution from agricultural production activities has not received enough attention. This paper focuses on agricultural air pollution in central China, which is aggravated by the ongoing rural labor migration trend. With a set of panel data released from Hubei and Hunan provinces in China, we adopt the mediating effect model to explore the relationship between rural labor migration and air pollution caused by agricultural activity in China. First, we use the inventory analysis method and principal component analysis method to calculate the comprehensive index of the air pollution of agriculture in 152 counties and districts from Hubei and Hunan provinces, and we empirically test the impact of labor migration on air pollution with a mediating effect model as well as carry out regional heterogeneity analysis on the pollution effect of these two provinces mentioned above. The analysis above indicates that the increase of labor migration has intensified the comprehensive index of air pollution caused by agricultural activity by changing the supply of labor force in the agricultural sector, the budget line of rural residents, and the scale of agricultural production and crop planting structure, but there is a difference in the indirect total effect between the two provinces mentioned above according to our regional heterogeneity analysis. This study is a necessary extension to studies on alleviating and controlling air pollution in China.
\end{abstract}

Keywords: agricultural air pollution; labor migration; mediation effect; income effect; economy of scale

\section{Introduction}

The current COVID-19 pandemic interrupted many production and industrial activities, but the agriculture industry seems to have suffered less. Evidence from Lovarelli's research suggests that during the quarantine, the increase in ammonia emissions is mainly due to agricultural production activities, as there was a significant reduction in transportation and industrial activities [1]. Air pollution control in rural areas has fallen into a state of considerable stress and crucial difficulty regarding protecting the environment and ecosystem in China, which has a direct influence on the process of China's sustainable development. There are two sources of air pollution: human activities and natural processes. Agricultural production is one of the typical human activities that brings air pollution. Hellin (2021) has evaluated the impact of agricultural production on the atmosphere in India, which confirmed that agricultural production will pollute the atmosphere [2].

Agricultural activities include cultivating the soil, producing crops, and raising livestock, most of which will pollute the atmosphere. Crop farming pollutes the atmosphere when straw is burned, pesticides are sprayed, and fertilizer is applied. In China, a large amount of straw is burned artificially in the open air after harvest, causing serious air pollution. The emissions from biomass combustion are considered to be the sources of 
greenhouse gases such as carbon dioxide, methane, and nitric oxide. In addition, aerosols emitted from biomass burning have high mass concentrations of $\mathrm{PM}_{2.5}$, organic carbon, elemental carbon, and potassium [3]. In Jiaodong Peninsula, the North China Plain, East China, and other areas, the particulate matter produced by farmland incineration of agricultural residues accounts for more than $35 \%$ of the aerosol optical thickness and more than $60 \%$ in some areas of Shandong, Henan, and Jiangsu provinces in China [4]. Agriculture is the second largest carbon emission source after power generation and waste gas, accounting for $14 \%$ of the total emissions of human activities in the world, according to the Intergovernmental Panel on Climate Change (IPCC) fourth assessment report in 2007. Furthermore, as a traditional agricultural country, China's agriculture has produced nearly 500 million tons of carbon dioxide emissions [5]. Wang (2022) introduced the ecosystem health risk index (EHR) to evaluate the impact of agricultural pollutants on the health of natural ecosystems and found that in the process of agricultural production related to nitrogen fertilizer, air pollutants (including $\mathrm{NH}_{3}$ and $\mathrm{N}_{2} \mathrm{O}$ ) cause much more damage to ecosystem health than soil or water pollutants [6]. There is also evidence from Stacy's research (2011) that the livestock industry will also exacerbate the degree of air pollution [7]. Huang (2020) found that livestock and fertilizer application are the two main $\mathrm{NH}_{3}$ emission sources that will exacerbate air pollution [8].

This paper has great significance regarding balancing urbanization and air pollution control in China. Over the past forty years, there has been a large scale of rural labor migration from the traditional agricultural sector to various types of non-farm employment in China. Guo's study show that they are also one of the most important driving forces to the emerging urbanization and rapid economic growth [9]. However, the ecosystem cannot be neglected in order to maintain the fast pace of the rural economy. Air pollution control in rural areas has become a crucial difficulty to the environment protection and sustainable development for China.

The vast peasantry are the major stakeholders of rural ecological environment status, whose economic and social behavior will also inevitably have a profound impact on agricultural air pollution. The continuous large-scale labor migration provides the internal impetus for the sustainable growth of the regional economy, but in Xu's study, it also affects the household land use arrangements [10], afterwards exerting an influence on agricultural air pollution.

\section{Theoretical Mechanism}

Agricultural air pollution refers to air pollutants generated during agricultural production activities, such as straw burning, application of volatile fertilizers, rural livestock feces, etc. Accordingly, by what means does the migration of the rural labor force change the mode of agricultural activities, therefore affecting the agricultural air pollution? Summarizing the currently available academic research, there are basically four paths listed as follows:

First, Bhandari et al. (2016) and Tian et al. (2020) suggested a substitution relationship between farming supplies such as chemical fertilizers and labor force in agricultural production $[11,12]$. Bounded by a limited labor force, farmers tend to increase their usage of farming supplies, especially chemical fertilizers to offset the shortage of labor force and gain the same amount of output. Likewise, Luan (2017) conducted an empirical study on the relationship between the outflow of rural labor force and the application of agricultural chemical fertilizer based on the panel data of major grain-growing provinces in China from 2004 to 2015. The regression results confirmed the substitution relationship between rural labor migration and fertilization [13]. Hence, there is the first hypothesis of this paper.

Hypothesis 1. Rural labor migration leads to the reduction of labor force supply for agricultural production, which increases the input intensity of farming supplies as its substitution factors and then aggravates the agricultural air pollution level. 
Second, there is the income effect. Changes in income shift the consumer choice, increasing or decreasing the consumption of consumables and other agricultural goods. According to the consumer equilibrium theory, under the condition of unchanged consumer utility preferences, income growth will expand the income constraints, thus affecting the demand for certain consumption. As a matter of fact, with different utility preferences, the impact of income growth on different variety of goods is also different.

Changes in income can also have an impact on labor supply. In the labor market, workers provide different amounts of work according to their income and leisure estimates at different wages, and the results are shown in two opposite dimensions. On one hand, a growth of wage rate increases the opportunity cost of leisure, which can result in a rise of working hours; on the other hand, a growth of wage rate increases the savings and consumption level of the workers, which then leads to an increase of the utility demand preference for leisure, thus bringing a reduction of the working time.

As for the influence of non-farm income on agricultural production, some scholars believed that the increase of non-farm income expanded the budget for their family members who were left behind in rural areas, providing them with the economic capacity of purchasing more farming supplies, resulting in applying more fertilizers (Goodwin and Mishra, 2004; Luan et al., 2016) [14,15]. On the contrary, some other scholars believe that the family's increased income is actually not for farming supplies but for household fixed assets investment, education, and life consumption. So, the increase in income does not affect the chemical fertilizers usage and does not exacerbate air pollution (Cheng et al., 2015) [16]. Meanwhile, the non-farm income increased opportunity costs for farming, leading to extensively rough agricultural management and even abandoned farmland, resulting in a decrease of various farming supplies including chemical fertilizers (Carletto et al., 2013; Qiu, 2018) [17,18].

Hypothesis 2. The migration of rural labor force leads to an increase of non-farm income. On one hand, it can increase the purchase and application of farming supplies because of the alleviating financial constraints, aggravating agricultural air pollution; on the other hand, it also increases the opportunity cost for farming, encouraging discarded farmland, which alleviates agricultural air pollution. The overall effect is uncertain.

Third, there is economy of scale. The transfer of land use rights can affect agricultural production efficiency by reducing the degree of land division and expanding the business scale, and it can also produce a "leveling effect", that is, the transfer of land use right from farmers with less land to farmers with more land. Based on the survey data of Southern Henan, a major grain-producing area in China, Gao (2020) conducted an empirical study on the impact of farmers' migration to rural land transfer using the threshold model and CHARLS 2015 data. This study empirically analyzed the impact of the labor migration scale on the ratio of rural transferred land to total land area and concluded that the migration of rural labor force has affected the turnover speed of farmland circulation and the concentration of agricultural operation [19]. The migration of labor force and the increase of non-farm income reduce the dependence of rural families on farmland, promoting the transfer of use rights of agricultural land, making extensive running possible and bringing more air pollution. Therefore, we have the third hypothesis of this paper:

Hypothesis 3. The migration of rural labor force accelerates the transfer of use rights of land and expands the production scale, thus improving the productivity efficiency of farming supplies, reducing the average application intensity, and then contributing to aggregating the agricultural air pollution.

Fourth, there is the effect of crop planting structure. Two different views appeared related to the impact of rural labor migration on the crop planting structure (proportion of cash crop planting area). From the perspective of the farmers' own families, Zhong et al. (2016) believed that the migration of the labor force reduces the core labor force of rural families, leading to the trend of farmers' aging and part-time agriculture. They prefer 
mechanized agriculture because mechanized agriculture is very convenient [20]. However, from the perspective of transfer of use rights of land, Wan (2014) believed that under the stimulation of maximizing short-term benefits, land contractors were more willing to shift from planting "safety first" food crops to cash crops with higher planting density, more complex compounds, and basically higher yield for production. It makes it difficult to control the application amount of pesticides, chemical fertilizers, and various additives, thus aggravating agricultural air pollution [21]. Consequently, there we have the fourth hypothesis of our research.

Hypothesis 4. There are two opposite dependent paths of how rural labor migration affects the agricultural crop planting structure, and therefore, the overall impact on agricultural air pollution is temporarily uncertain.

In summary of all the assumptions above, the substitution effect and economy of scale effect aggravate the pollution level of agricultural air; meanwhile, the influence of income effect and crop planting structure effect is temporarily uncertain. Therefore, the overall impact of rural labor force migration on agricultural air pollution needs to be tested.

\section{Data Description and Research Methodology}

\subsection{Data Description}

This paper selected the rural agricultural data from every county and district of Hubei and Hunan provinces from 2007 to 2017 in China as the data sample. All the underlying data involved are from the Statistical Yearbook, Rural Statistical Yearbook, and China County Statistical Yearbook of each province and city. Based on the availability of data, we remove outliers and deal with the missing values of some data with the method of line deduction in data from 69 counties and districts in Hubei Province and 83 counties and districts in Hunan Province. Finally, 152 counties and districts were retained as valid samples. To eliminate the possible heteroscedasticity of time-series data, some variables in this paper use natural logarithms in empirical analysis.

According to the research purpose, the comprehensive index of agricultural air pollution (AAPI) is taken as the prediction variable. The main explanatory variables are the scale of labor migration, per-capita non-farm income, farmland scale, and the cash crop ratio. In addition, other factors are considered as control variables, including the size of the rural population, the output of agricultural production, agricultural irrigation area, and the mechanical power for agricultural use.

Table 1 below clearly demonstrates the setting and statistical description of the variables. Among them, the minimum and maximum values of the core variable labor migration are 3.438 and 87.698 , respectively, with a standard deviation of 14.186. It reflects that the data samples of rural labor migration have great differences and changes in the region. The comprehensive index of agricultural air pollution was established based on principal component analysis (PCA). The minimum and maximum value of the comprehensive agricultural air pollution index are 0.445 and 34.686, respectively, with a standard deviation of 6.638. Large variations in variables can also meet research needs.

Figure 1 demonstrates a fitting diagram between the comprehensive index of agricultural air pollution (AAPI) and rural labor force migration in Hubei and Hunan provinces. It is obvious that there is a positive correlation between labor migration and agricultural air pollution, indicating that the higher the migration scale of rural labor force, the more serious the air pollution, providing an intuition to the preliminary research.

\subsection{Research Methodology}

\subsubsection{Inventory Analysis Method}

The inventory analysis method is commonly used in environmental pollution research. First, we determine the pollutant generating unit, and then, we use the pollutant producing coefficients and accounting formula of the pollutant producing unit to indirectly calculate 
the amount of agricultural pollution. The pollution production unit, pollution production coefficient, and accounting model constitute the core considerations of this method. In this paper, chemical fertilizers, straw, and mammal livestock are selected as the pollution production unit, referring to the study of Chen et al. (2006) and Fan (2014) [22,23].

Table 1. Variables setting and statistical description.

\begin{tabular}{|c|c|c|c|c|c|c|}
\hline Variable & Indicator & Unit & Mean & $\begin{array}{l}\text { Standard } \\
\text { Deviation }\end{array}$ & Min & Max \\
\hline $\begin{array}{l}\text { Rural labor } \\
\text { migration (LM) }\end{array}$ & $\begin{array}{c}\text { Rural non-farm payroll } \\
\text { employments/total rural labor force }\end{array}$ & $\%$ & 48.340 & 14.186 & 3.438 & 87.698 \\
\hline $\begin{array}{l}\text { Non-farm income } \\
\text { (NI) }\end{array}$ & $\begin{array}{l}\text { Per-capita non-farm income of rural } \\
\text { residents }\end{array}$ & $\begin{array}{l}\text { hundred US } \\
\text { dollars }\end{array}$ & 12.689 & 7.351 & 1.413 & 46.880 \\
\hline Farmland scale (FS) & $\begin{array}{c}\text { Total cultivated farmland/total } \\
\text { number of agricultural } \\
\text { employments }\end{array}$ & $\begin{array}{l}0.1 \text { hectare } \\
\text { per person }\end{array}$ & 7.112 & 3.435 & 2.224 & 24.697 \\
\hline $\begin{array}{l}\text { Cash crop ratio } \\
\text { (CCR) }\end{array}$ & $\begin{array}{c}\text { Cash crop sown area/total sown } \\
\text { area }\end{array}$ & $\%$ & 41.724 & 9.819 & 7.468 & 69.393 \\
\hline $\begin{array}{l}\text { Rural population } \\
\text { (Rpop) }\end{array}$ & Rural resident population & ten thousand & 40.799 & 22.518 & 2.330 & 129.250 \\
\hline $\begin{array}{l}\text { Agricultural output } \\
\text { (Aoutput) }\end{array}$ & $\begin{array}{l}\text { Gross output of agricultural } \\
\text { production at constant price }\end{array}$ & 100 million & 47.687 & 33.875 & 1.274 & 208.257 \\
\hline $\begin{array}{l}\text { Total mechanical } \\
\text { power (Mpower) }\end{array}$ & $\begin{array}{l}\text { Total energy consumption of } \\
\text { agricultural machinery }\end{array}$ & 10 megawatts & 47.819 & 34.165 & 0.679 & 178.249 \\
\hline $\begin{array}{l}\text { Agricultural } \\
\text { irrigation area } \\
\text { (Irrigation) }\end{array}$ & $\begin{array}{l}\text { Total area of cultivated farmland for } \\
\text { agricultural irrigation }\end{array}$ & $\begin{array}{l}\text { thousands of } \\
\text { hectares }\end{array}$ & 32.852 & 26.097 & 0.770 & 206.390 \\
\hline
\end{tabular}
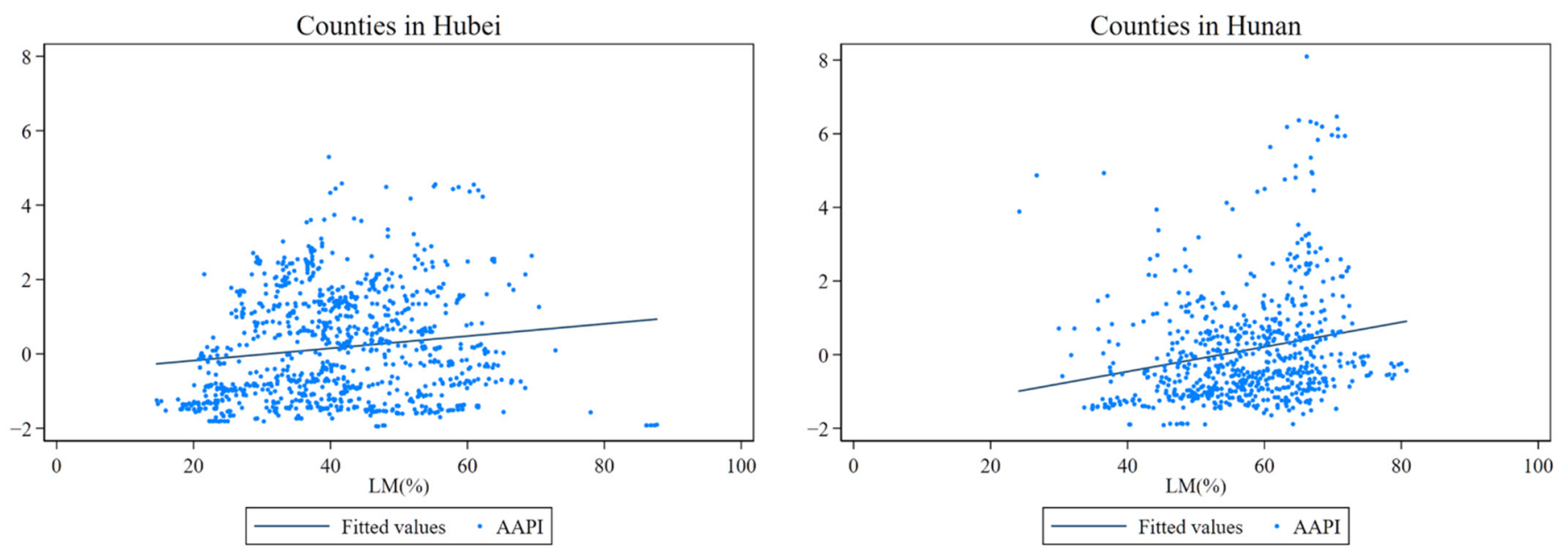

Figure 1. AAPI and rural labor migration (LM, \%) of counties in Hubei and Hunan.

According to the above text, we know that agricultural activity affects air pollutants mainly by crop farming and livestock breeding. Hence, it is reasonable to choose an index related to crop farming and livestock breeding. We use nitrogenous fertilizer and application to describe the chemical fertilizer part because nitrogenous fertilizer is one of the main sources of air pollutants such as $\mathrm{N}_{2} \mathrm{O}$ and $\mathrm{NH}_{3}$. Yichao Wang (2020) calculated cropland $\mathrm{N}_{2} \mathrm{O}$ and $\mathrm{NH}_{3}$ emission factors from fertilized farmland, and we adapt this index [6]. Straw residue burning is one of the most important polluting agricultural activities that affects the atmosphere, and we choose the total output of rice, maize, wheat, beans, and tubers and other air pollutants emitted via straw burning to calculate air 
pollutants emitted via straw burning. The grain-straw ratio and straw open burning ratio in Hubei and Hunan are from Cao's research in 2005 [24]. Livestock breeding also contaminates air quality, and ammonia $\left(\mathrm{NH}_{3}\right)$ emissions, the majority of which arise from livestock production, are linked to the high concentration of $\mathrm{PM}_{2.5}$ and degraded air quality in China, according to Haodan Wang's study in 2021. The $\mathrm{NH}_{3}$ emitted ratio from livestock breeding is from Wang's paper and livestock breeding total nitrogen are selected from the announcements published by the Ministry of Ecology and Environment of China [25,26]. Other data are collected from China rural statistical yearbook, and China County Statistical Yearbook. The specific accounting method is shown in Table 2.

Table 2. Accounting method of pollution production unit.

\begin{tabular}{|c|c|c|c|c|}
\hline $\begin{array}{l}\text { Agricultural } \\
\text { Activity }\end{array}$ & \multicolumn{2}{|c|}{ Category } & Accounting Method & Result \\
\hline \multirow[b]{2}{*}{ Crop farming } & $\begin{array}{l}\text { chemical } \\
\text { fertilizer }\end{array}$ & $\begin{array}{l}\text { rice } \\
\text { maize } \\
\text { wheat }\end{array}$ & $\begin{array}{l}\text { The amount of fertilizer air pollutants }=\text { crop planting area(ha) } \times \\
\text { cropland emission factors }\left(\mathrm{N}_{2} \mathrm{O} \text { and } \mathrm{NH}_{3} ; \mathrm{kg} / \mathrm{ha}\right)\end{array}$ & \multirow{3}{*}{$\begin{array}{c}\text { Total } \\
\text { agricultural } \\
\text { emission of } \\
\text { multiple air } \\
\text { pollutants }(\mathrm{kg})\end{array}$} \\
\hline & straw & $\begin{array}{l}\text { rice } \\
\text { maize } \\
\text { wheat } \\
\text { beans } \\
\text { tubers }\end{array}$ & $\begin{array}{l}\text { The amount of air pollutants emitted via straw burning = total crop } \\
\text { output } \times \text { grain-straw ratio }{ }^{-1} \times \text { straw open burning ratio }(\text { of } \mathrm{Hubei} \\
\text { and Hunan, estimated }) \times \text { emission factors }\left(\mathrm{CH}_{4}, \mathrm{NH}_{3}, \mathrm{SO}_{2}, \mathrm{NO}_{2}, \mathrm{PM}_{2.5}\right. \\
\mathrm{g} / \mathrm{kg}) / 1000\end{array}$ & \\
\hline $\begin{array}{l}\text { Livestock } \\
\text { breeding }\end{array}$ & $\begin{array}{l}\text { livestock } \\
\text { waste }\end{array}$ & $\begin{array}{l}\text { hog } \\
\text { cattle } \\
\text { fowl }\end{array}$ & $\begin{array}{l}\text { The amount of livestock air pollutants }=\text { livestock breeding numbers } \\
\times \text { livestock breeding total nitrogen }(\mathrm{TN}, \mathrm{g} / \text { day per animal) coefficient } \\
\times \text { livestock output average duration }(\text { day }) \times \mathrm{NH}_{3} \text { emitted ratio/1000 }\end{array}$ & \\
\hline
\end{tabular}

3.2.2. Principal Component Analysis (PCA) on the Agricultural Air Pollution Comprehensive Index (AAPI) as the Dependent Variable in Subsequent Regression Model

Principal component analysis is a statistical method. Through the orthogonal transform, a set of possible relevant variables was transformed into a set of uncorrelated variables. The transformed group of variables is called the principal component.

In order to simplify the steps of regression, the agricultural air pollutants comprehensive index (AAPI) is calculated by synthesizing the air pollutants released by chemical fertilizer (CF), air pollutants emitted via straw burning (ST), and air pollutants released by livestock breeding (LS) using principal component analysis (PCA). Based on the principle of a feature root greater than 1, a principal component, indicated as "comp" reflecting the comprehensive level of agricultural air pollutants of the total sample, is extracted, with a feature root of 2.595 and a variance interpretation of $86.51 \%$, and the calculation function is shown as:

$$
\text { comp }=0.602 \times \mathrm{CF}+0.583 \times \mathrm{ST}+0.546 \times \mathrm{LS} .
$$

\subsubsection{Causal Steps Approach in Mediating Effect Model}

Mediating effect models are often used to study the complex process and mechanism of the explanatory variables on the predicted variables. Mediation effects are indirect effects and can be modeled using structural equation models. The main methods to test the mediation effect include the product of coefficient approach, causal steps regression test, and significance test of difference (Wen et al., 2004) [27]. To examine the mechanism by which the rural labor migration affects agricultural production activities, thereby affecting agricultural air pollutants, this paper selected the causal steps approach, a more commonly used method by domestic scholars, to test the mediation effect in this scenario. Under the assumptions of the hypothesis mentioned previously, the following five regression equations are set to constitute the mediating effect model as Function (1) to (5):

$$
\ln A A P I_{i t}=\alpha_{i}+\beta_{0} L M_{i t}+\sum_{j} \beta_{j} X_{i t}+v_{t}+\xi_{i t}
$$




$$
\begin{gathered}
\ln N I_{i t}=\alpha_{i}+\lambda_{1} L M_{i t}+\sum_{j} \lambda_{j} X_{i t}+v_{t}+\xi_{i t} \\
\ln F S_{i t}=\alpha_{i}+\pi_{1} L M_{i t}+\sum_{j} \pi_{j} X_{i t}+v_{t}+\xi_{i t} \\
C C R=\alpha_{i}+\theta_{1} L M_{i t}+\sum_{j} \theta_{j} X_{i t}+v_{t}+\xi_{i t} \\
\ln A A P I_{i t}=\alpha_{i}+\beta_{1} L M_{i t}+\rho_{1} \ln N I_{i t}+\rho_{2} \ln F S_{i t}+\rho_{3} C C R_{i t}+\sum_{j} \beta_{j} X_{i t}+v_{t}+\xi_{i t}
\end{gathered}
$$

$X$ are control variables, including the rural population size, agricultural production, agricultural irrigation, and agricultural machinery power; these control variables affect the degree of agricultural air pollution. $\alpha$ is the constant of the regression, $v$ is the time variable, and $\xi$ represents the regression residual in the equation. Among them, Function (1) is the benchmark equation for the agricultural air pollutants comprehensive index; Function (2) to (4) test the mediation effect of the income effect, the economy of scale effect, and the effect of the crop-planting structure, respectively; Function (5) combines the direct effect variable labor migration (LM) with the mediation effect variables of non-farm income (NI), farmland scale (FS), and cash crop ratio (CCR) to measure the total effect on agricultural air pollution.

\section{Analysis Process}

In order to exclude heteroscedasticity, some variables were converted to their logarithmic form and estimated using the fixed effect model (FE) based on the $p$ value of the Hausman test being zero.

\subsection{Total Sample Analysis: The Effect of Labor Migration on Agricultural Air Pollution}

Table 3 shows the impact results of labor migration, LM, on the comprehensive index of agricultural air pollution, AAPI.

Based on the research design of Model (1-1) to (1-5) presented in the previous section, the calculation of the pollution effect of rural labor migration is divided into the following three steps:

\subsubsection{Benchmark Model Test}

The explanatory variables in Model (1-1) include only labor migration variables and four related controlled variables, which is the benchmark model to test the significance of rural labor migration on the AAPI. In the results, the coefficient of labor migration is significantly positive (0.0023), which suggests that the total effect of labor migration on AAPI is positive. This is consistent with the previous theoretical hypothesis.

\subsubsection{Mediation Test of Indirect Effect of Labor Migration}

In the second step, we tested the mediation effect variables (non-farm income, farmland scale, and crop-planting structure) with Model (1-2), (1-3), and (1-4) separately. The test results show that the coefficient of rural labor migration on the non-farm income variable and farmland scale variable are significantly positive $(0.1248$ and 0.159$)$, which means that the migration of rural labor force has improved the per-capita income of rural resident households, promoting farmland concentration and increasing the per-capita farmland for rural residents. Whereas, the coefficient of rural labor migration on the crops planting structure variable is not significant, suggesting that the migration of labor force in Hubei and Hunan provinces has not significantly increased the proportion of cash crops, also confirming the research conclusion from Zhong (2016) [20]. 
Table 3. Results of mediating effect model analysis.

\begin{tabular}{|c|c|c|c|c|c|}
\hline \multirow[b]{2}{*}{ Model } & $1-1$ & $1-2$ & $1-3$ & $1-4$ & $1-5$ \\
\hline & Benchmark Model & \multicolumn{3}{|c|}{$\begin{array}{c}\text { Mediation Test of the Income, Scale and Crop-Planting Structure } \\
\text { Effect of Rural Labor Force Migration }\end{array}$} & $\begin{array}{l}\text { Direct and Indirect } \\
\text { Effect of Labor } \\
\text { Migration on AAPI }\end{array}$ \\
\hline Variable & $\ln \mathrm{AAPI}^{1}$ & $\ln \mathrm{NI}$ & $\operatorname{lnFS}$ & CCR & $\ln \mathrm{AAPI}$ \\
\hline $\ln \mathrm{NI}$ & & & & & $\begin{array}{l}0.0564 * 2 \\
(0.0294)^{3}\end{array}$ \\
\hline $\operatorname{lnFS}$ & & & & & $\begin{array}{l}0.1970 * * * \\
(0.0467)\end{array}$ \\
\hline CCR & & & & & $\begin{array}{l}-0.0098 * * * \\
(0.0013)\end{array}$ \\
\hline \multirow{2}{*}{ LM } & $0.0023^{* * *}$ & $0.1248^{* * *}$ & $0.1590^{* * *}$ & -0.0396 & $-0.0030 * *$ \\
\hline & $(0.0006)$ & $(0.0474)$ & $(0.0229)$ & $(0.0990)$ & $(0.0013)$ \\
\hline \multirow{2}{*}{$\operatorname{lnRpop}$} & $0.0869 *$ & -0.0452 & $-0.0347^{* *}$ & -0.0041 & $0.0899 *$ \\
\hline & $(0.0453)$ & $(0.0471)$ & $(0.0227)$ & $(0.0169)$ & $(0.0455)$ \\
\hline \multirow{2}{*}{ lnAoutput } & $0.227 * * *$ & $1.1279 * * *$ & $0.3005^{* * *}$ & $0.0622 * * *$ & $0.2080 * * *$ \\
\hline & $(0.0679)$ & $(0.0402)$ & $(0.0194)$ & $(0.0143)$ & $(0.0693)$ \\
\hline \multirow{2}{*}{ lnMpower } & $0.0724 * *$ & $0.2557^{* * *}$ & 0.0227 & 0.0082 & $0.0724 * *$ \\
\hline & $(0.0330)$ & $(0.0532)$ & $(0.0256)$ & $(0.0190)$ & $(0.0307)$ \\
\hline \multirow{2}{*}{ lnIrrigation } & 0.0443 & $0.1008^{* * *}$ & $-0.0745^{* *}$ & $0.0621 *$ & 0.0334 \\
\hline & $(0.0332)$ & $(0.0303)$ & $(0.0146)$ & $(0.0108)$ & $(0.0351)$ \\
\hline \multirow{2}{*}{ Constant } & $-0.966^{* *}$ & $-1.399 * * *$ & $0.4488^{* * *}$ & $3.6953 * * *$ & $-0.802 * *$ \\
\hline & $(0.381)$ & $(0.2561)$ & $(0.1234)$ & $(0.0916)$ & $(0.390)$ \\
\hline Fixed location & controlled & controlled & controlled & controlled & controlled \\
\hline Fixed time & controlled & controlled & controlled & controlled & controlled \\
\hline R-sq & 0.289 & 0.6951 & 0.3550 & 0.0312 & 0.362 \\
\hline rho & 0.9707 & 0.8994 & 0.8451 & 0.8595 & 0.9692 \\
\hline Observations & 1672 & 1672 & 1672 & 1672 & 1672 \\
\hline Number of ids & 152 & 152 & 152 & 152 & 152 \\
\hline Direct effect & & Indire & regate) & & Total effect \\
\hline-0.0030 & & & & & 0.0353 \\
\hline
\end{tabular}

${ }^{1}$ Abbreviations are used for the following variables: logarithmic comprehensive index of agricultural air pollution (lnAAPI), logarithmic non-farm income (lnNI), logarithmic farmland scale(lnFS), cash crop ratio (CCR), labor migration ratio (LM), logarithmic rural population (lnRpop), logarithmic agricultural output (lnAoutput), logarithmic mechanical power (lnMpower), the same below. ${ }^{2}$ The asterisks indicate different significance levels, ${ }^{* * *}$ for $p<0.01,{ }^{* *}$ for $p<0.05$, and ${ }^{*}$ for $p<0.1$, the same below. ${ }^{3}$ Content in brackets is the standard error, the same below.

\subsubsection{Calculation of the Direct Effect and Indirect Effect}

Model (1-5) includes rural labor migration and indirect variables, controlled variables into the regression model, testing the direct factor substitution effect, indirect effect, and total effect of labor force migration on the AAPI.

First, the study found that the direct effect, indirect income, and scale effects of labor migration have passed the statistical significance test, so the impact effect of labor migration on agricultural air pollution is manifested as a partial mediation effect.

Next, the report results indicate that the influence coefficient of the non-farm income variable is 0.0564 , that is, the increase of non-farm income has a significantly positive correlation on the AAPI. This can be interpreted in that the increase of household income greatly increases the farming materials and chemical fertilizer, which aggravates agricultural air pollution. The mediation effect of scale variable has a significantly positively correlation, which is in line with Hypothesis 3. A peasant who manages more land than his/her capacity will lead to extensive operation, using more fertilizer and bringing more air pollution. In addition, the coefficient of crop-planting structure variable is significantly negative. According to Hypothesis 4, it can be interpreted that this non-grain trend of crop-planting structure will alleviate agricultural air pollution, but provided the result of Model (1-4), the coefficient of mediator structure variable is not significant, so the indirect effect of crop-planting structure is not included in the aggregate indirect effect calculation.

Finally, the premise of the total effect calculation is that the coefficient must be statistically significant. According to this screening, the coefficient of the direct effect is -0.0030 ; the indirect income effect is 0.0070 (indirect income effect is calculated as: 
$0.1248 \times 0.0564=0.0070$, the coefficients of non-farm income from Model (1-2) and (1-5); accordingly, indirect scale and structure effect are calculated in the same way), the scale indirect effect is 0.0313 , the structure effect is not significant, so the aggregate indirect effect is 0.0383 . The total effect is the sum of the direct effect and the aggregate indirect effect, that is, 0.0353 .

It is also evident to analyze the other controlled variables to find that the influence coefficients of rural population, agricultural output value, and mechanical power on the AAPI are significantly positive, and the coefficients are $0.0869,0.227$, and 0.0724 . Among them all, the output of agricultural production is undoubtedly the main culprit of agricultural air pollution.

\subsection{Heterogeneity Analysis: The Regional Analysis of Rural Labor Migration in Hubei and Hunan}

The original data show that the overall number of rural labor migration in Hubei Province is significantly lower than that in Hunan province, which supports the further exploring of the discriminative results of them. In this section, we divided the samples into two sub-sample sets and carried out the same test as the previous section. Tables 4 and 5 are the results of it in Hubei Province and Hunan Province, respectively.

Table 4. Heterogeneity analysis: results of mediating effect model analysis in Hubei Province.

\begin{tabular}{|c|c|c|c|c|c|}
\hline \multirow[b]{2}{*}{ Model } & $2-1$ & $2-2$ & $2-3$ & $2-4$ & $2-5$ \\
\hline & Benchmark Model & \multicolumn{3}{|c|}{$\begin{array}{c}\text { Mediation Test of the Income, Scale, and Crop-Planting Structure } \\
\text { Effect of Rural Labor Force Migration }\end{array}$} & $\begin{array}{l}\text { Direct and Indirect } \\
\text { Effect of Labor } \\
\text { Migration on AAPI }\end{array}$ \\
\hline Variable & $\ln \mathrm{AAPI}$ & $\ln \mathrm{NI}$ & $\operatorname{lnFS}$ & CCR & $\ln \mathrm{AAPI}$ \\
\hline $\ln \mathrm{NI}$ & & & & & $\begin{array}{c}0.0285 \\
(0.0232)\end{array}$ \\
\hline $\operatorname{lnFS}$ & & & & & $\begin{array}{l}0.238 * * * \\
(0.0412)\end{array}$ \\
\hline CCR & & & & & $\begin{aligned}-0.0071 * * * \\
(0.0011)\end{aligned}$ \\
\hline \multirow{2}{*}{ LM } & 0.0002 & $0.2241 * *$ & $0.1813^{* * *}$ & $-0.1194^{* * *}$ & $-0.0055^{* * *}$ \\
\hline & $(0.0007)$ & $(0.1101)$ & $(0.0481)$ & $(0.0343)$ & $(0.00125)$ \\
\hline \multirow{2}{*}{$\ln R$ pop } & $0.589 * * *$ & $-0.1964^{* *}$ & -0.0283 & -0.0159 & $0.639 * * *$ \\
\hline & $(0.153)$ & $(0.0907)$ & $(0.0396)$ & $(0.0282)$ & $(0.142)$ \\
\hline \multirow{2}{*}{$\ln$ Aoutput } & $0.212 * * *$ & $0.8540^{* * *}$ & $0.2690^{* * *}$ & 0.0207 & $0.186^{* * *}$ \\
\hline & $(0.0439)$ & $(0.07462)$ & $(0.0326)$ & $(0.0232)$ & $(0.0406)$ \\
\hline \multirow{2}{*}{ lnMpower } & 0.00257 & $0.3238^{* * *}$ & $0.0898 *$ & -0.0176 & 0.0093 \\
\hline & $(0.0148)$ & $(0.1084)$ & $(0.0474)$ & $(0.0338)$ & $(0.0130)$ \\
\hline \multirow{2}{*}{ lnIrrigation } & -0.0358 & $0.2019 * * *$ & $0.0782 * * *$ & -0.0163 & -0.0198 \\
\hline & $(0.0230)$ & $(0.0443)$ & $(0.0194)$ & $(0.0138)$ & $(0.0192)$ \\
\hline \multirow{2}{*}{ Constant } & $-1.965 * * *$ & $-0.9428 *$ & $0.4365 * *$ & $4.2857 * * *$ & $-2.111 * * *$ \\
\hline & $(0.454)$ & $(0.5652)$ & $(0.2471)$ & $(0.1761)$ & $(0.449)$ \\
\hline Fixed location & control & control & control & control & control \\
\hline Fixed time & control & control & control & control & control \\
\hline R-sq & 0.317 & 0.6038 & 0.3667 & 0.0214 & 0.369 \\
\hline rho & 0.9665 & 0.7251 & 0.6746 & 0.8581 & 0.9525 \\
\hline Observations & 759 & 759 & 759 & 759 & 913 \\
\hline Number of ids & 69 & 69 & 69 & 69 & 83 \\
\hline Direct effect & & Indirect & gated) & & Total effect \\
\hline-0.0055 & & & & & 0.0385 \\
\hline
\end{tabular}

1 Abbreviations are used for the following variables: logarithmic comprehensive index of agricultural air pollution (lnAAPI), logarithmic non-farm income (lnNI), logarithmic farmland scale(lnFS), cash crop ratio (CCR), labor migration ratio (LM), logarithmic rural population (lnRpop), logarithmic agricultural output (lnAoutput) logarithmic mechanical power (lnMpower), the same below. ${ }^{2}$ The asterisks indicate different significance levels, $* * *$ for $p<0.01,{ }^{* *}$ for $p<0.05$, and ${ }^{*}$ for $p<0.1 .{ }^{3}$ Content in brackets is the standard error. 
Table 5. Heterogeneity analysis: results of mediating effect model analysis in Hunan Province.

\begin{tabular}{|c|c|c|c|c|c|}
\hline \multirow[b]{2}{*}{ Model } & 3-1 & $3-2$ & $3-3$ & $3-4$ & $3-5$ \\
\hline & Benchmark Model & \multicolumn{3}{|c|}{$\begin{array}{c}\text { Mediation Test of the Income, Scale, and Crop-Planting Structure } \\
\text { Effect of Rural Labor Force Migration }\end{array}$} & $\begin{array}{l}\text { Direct and Indirect } \\
\text { Effect of Labor } \\
\text { Migration on AAPI }\end{array}$ \\
\hline \multirow{2}{*}{$\begin{array}{l}\text { variable } \\
\ln \mathrm{NI}\end{array}$} & $\ln \mathrm{AAPI}$ & $\ln \mathrm{NI}$ & $\operatorname{lnFS}$ & CCR & $\ln \mathrm{AAPI}$ \\
\hline & & & & & $\begin{array}{l}0.393^{* *} \\
(0.173)\end{array}$ \\
\hline \multirow[t]{2}{*}{$\operatorname{lnFS}$} & & & & & 0.0836 \\
\hline & & & & & $(0.0710)$ \\
\hline \multirow[t]{2}{*}{ CCR } & & & & & $-0.0113^{* * *}$ \\
\hline & & & & & $(0.0021)$ \\
\hline \multirow[t]{2}{*}{ LM } & $0.0028 * *$ & $0.0906 * *$ & $0.1482 * * *$ & -0.0109 & 0.0001 \\
\hline & $(0.0011)$ & $(0.0371)$ & $(0.0241)$ & $(0.0175)$ & $(0.0021)$ \\
\hline \multirow[t]{2}{*}{$\ln R p o p$} & 0.0247 & -0.0021 & $-0.0375 *$ & -0.2061 & 0.00644 \\
\hline & $(0.0182)$ & $(0.0409)$ & $(0.0202)$ & $(0.0193)$ & $(0.0168)$ \\
\hline \multirow[t]{2}{*}{$\ln$ Aoutput } & 0.136 & $1.4673^{* * *}$ & $0.3131^{* * *}$ & $0.1509 * * *$ & $0.197^{* *}$ \\
\hline & $(0.0878)$ & $(0.0373)$ & $(0.0242)$ & $(0.0176)$ & $(0.0828)$ \\
\hline \multirow[t]{2}{*}{ lnMpower } & $0.247^{* *}$ & $0.1833^{* * *}$ & -0.0176 & 0.0035 & $0.253^{* * *}$ \\
\hline & $(0.111)$ & $(0.0446)$ & $(0.0290)$ & $(0.0211)$ & $(0.0945)$ \\
\hline \multirow[t]{2}{*}{ lnIrrigation } & $0.0703^{* *}$ & -0.0181 & $-0.0627^{* *}$ & -0.0134 & 0.0428 \\
\hline & $(0.0350)$ & $(0.0395)$ & $(0.0256)$ & $(0.0187)$ & $(0.0345)$ \\
\hline \multirow[t]{2}{*}{ Constant } & $-1.205^{*}$ & $-1.7712 * * *$ & $0.3872 * * *$ & $3.3162 * * *$ & $-2.151 * * *$ \\
\hline & $(0.619)$ & $(0.2092)$ & $(0.1358)$ & $(0.0988)$ & $(0.788)$ \\
\hline Fixed location & control & control & control & control & control \\
\hline Fixed time & control & control & control & control & control \\
\hline R-sq & 0.488 & 0.8456 & 0.3429 & 0.1714 & 0.553 \\
\hline rho & 0.9583 & 0.9723 & 0.8378 & 0.9007 & 0.9511 \\
\hline Observations & 913 & 913 & 913 & 913 & 759 \\
\hline Number of ids & 83 & 83 & 83 & 83 & 69 \\
\hline Direct effect & \multicolumn{4}{|c|}{ Indirect effect (aggregated) } & Total effect \\
\hline $\begin{array}{c}\text { Not } \\
\text { significant }\end{array}$ & \multicolumn{4}{|c|}{0.0356} & 0.0356 \\
\hline
\end{tabular}

${ }^{1}$ Abbreviations are used for the following variables: logarithmic comprehensive index of agricultural air pollution (lnAAPI), logarithmic non-farm income (lnNI), logarithmic farmland scale(lnFS), cash crop ratio (CCR), labor migration ratio (LM), logarithmic rural population (lnRpop), logarithmic agricultural output (lnAoutput), logarithmic mechanical power (lnMpower), the same below. ${ }^{2}$ The asterisks indicate different significance levels, ${ }^{* * *}$ for $p<0.01,{ }^{* *}$ for $p<0.05$, and * for $p<0.1{ }^{3}$ Content in brackets is the standard error.

\subsubsection{Benchmark Model Test of Hubei and Hunan Provinces, Separately}

In the Model (2-1) and (3-1), the coefficients of the rural labor force migration variables on the AAPI are both positive, but in Hubei, it is not significant. Moreover, rural labor migration in counties in Hunan is higher than that in Hubei, the coefficient of rural labor migration variables in counties on the pollution index in Hubei Province is higher by $0.0026 \%$ than that in Hunan Province as a result.

\subsubsection{Analysis of the Mediation Variables}

In Model (2-2) and (2-3) of Hubei Province, we showed that the income intermediary variables and scale mediation variable coefficient of rural labor migration are significant, 0.2241 and 0.1813, and Model (3-2) and (3-3) of Hunan Province present that the coefficients of the income mediation variable and scale mediation variable are 0.0906 and 0.1482 . The income effect and scale effect of rural labor migration in the two provinces are likewise significant, which indicates that the migration of rural labor force has also increased the household income and the rural per-capita cultivated land area. However, the difference lies in that the crop-planting structure effect of the counties in Hunan Province is negative but not significant; meanwhile, the structure effect coefficient of the counties in Hubei Province is significant negative. According to the study of Zhong (2016), it is mainly because the crop-planting structure of Hubei Province is relatively flexible, considering that the labor migration reduces the agricultural young and middle-aged labor force, and the convenience of mechanical operation for replacing manpower, labor migration substantially increases the proportion of food crops planted [20]. 


\subsubsection{Calculation of the Mediation and Total Effect in Hubei and Hunan Provinces}

The results of counties in Hubei show that although the direct effect is negative $(-0.0055)$, the indirect effect is large enough to make the total effect positive (0.0385). In other words, the migration of labor force has generally improved the level of agricultural air pollution in Hubei Province. In addition, the income effect is not significant, and the farmland scale effect is dominant in the indirect effect (0.0431 out of 0.044).

In Hunan Province, the results are not all alike. Only the income effect on the pollution index is significantly positive (0.0356), while all other direct and indirect coefficients are not. Therefore, the total effect of labor migration on AAPI is entirely explained by income indirect effect. In other words, the migration of labor force has generally increased the agricultural air pollution in Hunan Province through the non-farm income indirect effect.

Comparing the results of these two provinces, we can draw such a conclusion: there are many practical factors, such as agricultural traditions, terrain, economic level, etc., which together lead to the difference in direct and indirect effects on pollution between the two. However, the effect of labor migration cannot be ignored, a higher migration ratio will lead to a more significant indirect and total effect.

Finally, in each province, the indirect and total effect of rural labor migration on agricultural air pollution is consistent with the results from the whole sample. This indicates that our previous analysis is generally applicable to each province, with minor differences in indirect effects.

\subsection{Preliminary Summary}

In this section, we introduced and calculated an index, AAPI, to evaluated the air pollutant emission from agricultural production activities and conducted research on the connection between agricultural air pollution and rural labor migration. The above studies can be summarized in Table 6 .

Table 6. Summary of the pollution effect and decomposition conclusions of rural labor transfer.

\begin{tabular}{|c|c|c|c|c|c|c|}
\hline \multirow[b]{2}{*}{ Sample } & \multirow[b]{2}{*}{$\begin{array}{l}\text { Direct } \\
\text { Effect }\end{array}$} & \multicolumn{4}{|c|}{ Indirect Effect } & \multirow[b]{2}{*}{ Total Effect } \\
\hline & & $\begin{array}{c}\text { Income } \\
\text { Effect }\end{array}$ & $\begin{array}{c}\text { Land Scale } \\
\text { Effect }\end{array}$ & $\begin{array}{l}\text { Crop-Planting } \\
\text { Structure } \\
\text { Effect }\end{array}$ & $\begin{array}{l}\text { Indirect } \\
\text { Effect }\end{array}$ & \\
\hline $\begin{array}{c}\text { Total } \\
\text { sample }\end{array}$ & -0.0030 & 0.0070 & 0.0313 & $\begin{array}{c}\text { Not } \\
\text { significant }\end{array}$ & 0.0383 & 0.0353 \\
\hline Hubei province & -0.0055 & $\begin{array}{c}\text { Not } \\
\text { significant }\end{array}$ & 0.0431 & 0.0008 & 0.0440 & 0.0385 \\
\hline $\begin{array}{l}\text { Hunan } \\
\text { province }\end{array}$ & $\begin{array}{c}\text { Not } \\
\text { significant }\end{array}$ & 0.0356 & $\begin{array}{c}\text { Not } \\
\text { significant }\end{array}$ & $\begin{array}{c}\text { Not } \\
\text { significant }\end{array}$ & 0.0356 & 0.0356 \\
\hline
\end{tabular}

First, the increase of rural labor migration has a significant impact on both the mediator variables of non-farm income and farmland scale, but there is a difference in the indirect effect between the two provinces mentioned above according to our regional heterogeneity analysis. In general, the crop-planting structure effect of rural labor migration is not significant, but the income effect and scale effect are significant, indicating that a higher proportion of labor migration will not increase the proportion of cash crops obviously, but it does through the increase of non-farm income, which increases the opportunity cost of farming and discourages the labor force to farm, leading to an acceleration of the transfer of use rights of farmland, enlarging the per-capita farming area. In addition, certain differences occur in the rural labor migration on the mediator variables between two provinces. The income effect and scale effect of labor migration on the two provinces are both significant, but in Hubei, the impact of labor migration on the crop-planting structure is also significant, but the coefficient is negative; namely, in Hubei, labor migration actually increased the proportion of food crops. 
Second, in the overall sample, a higher proportion of labor migration has exacerbated the level of agricultural air pollution, and it mainly comes from the indirect effect, specifically, from income effect and scale effect. The direct effect of migration on pollution is less significant compared with its indirect effect.

Third, there are heterogeneity differences between the two provinces. For the counties in Hubei province, the migration of rural labor has less of a direct effect on agricultural air pollution than that in Hunan; Figure 1 clearly shows this difference.

\section{Conclusions and Discussion}

\subsection{Conclusions}

Nowadays, air pollutant emissions from agriculture have increased tremendously, and it is imperative to contain this trend in China to ensure the sustainability of agricultural production, the health of the rural population, and the development of rural economy.

This paper mainly analyzed the effect of rural labor migration on agricultural air pollution. First, we conducted mechanism research on the internal connection between agricultural air pollution and rural labor migration and put forward some hypotheses. Second, we evaluated air pollutant emission from agricultural production activities by introducing a new index air pollution comprehensive index (AAPI), and we calculated it with the data from counties in Hubei and Hunan. Lastly, we used the empirical method to examine the hypotheses above and obtained some conclusions.

We found that the increase of labor migration could intensify the air pollution discharged from agricultural activity by changing the following factors: the supply of labor force in the agricultural sector, the budget line of rural residents, and the scale of crop farming and planting structure; among them, the income and scale factor plays the major role. However, there is a difference in the indirect total effect between two provinces according to our regional heterogeneity analysis.

We attempt to propose some policy implications from the studies above. The intrinsic driving force of rural labor force migration lies in the surplus of labor force and the gap between urban and rural development. Its flow trend will continue, but the rural environmental protection should also not be ignored. From the study, we already know that with the transfer of rural population, the income, and living conditions of rural residents have been improved (mainly from family members who emigrated to the city), and the per-capita farming scale has also increased, which will not only increase the application of chemical fertilizer but also promote the extensive management in the agricultural production process, resulting in more air pollution. Therefore, increasing the investment and promotion of green agricultural production technology and providing more technical training for the remaining farmers should be put on the agenda to alleviate the air pollution caused by agricultural production.

\subsection{Discussion}

The potential theoretical contributions of this paper are as follows. First, we applied the PCA method and used a wider catalogue to calculate a more comprehensive index to evaluate agricultural air pollution rather than focus on a certain agricultural sector or a specific pollutant (such as nitrogen oxides and ammonia). Furthermore, the existing studies have focused on exploring the factors influencing agricultural air pollution from a specific and ecological perspective, but there has been an absence of mechanism studies about sociological and economic factors behind the countryside and agricultural activities. This paper could be a necessary supplement to this field.

This paper also has some study limitations. The data collected from Hubei and Hunan provinces are still insufficient to comprehensively measure the air pollution of agricultural production, so are the relevant pollution calculating coefficients and index. Further research is needed in these aspects. In addition, the mediating effect model we used in this paper is still an imperfect method for this research. The causal steps approach model is the most commonly used and convenient method compared with other mediating effect models, 
but there must be a situation in which the direct and indirect effects are similar or have opposite symbols and even affect the overall relationship between dependent variables and independent variables. Therefore, the stepwise test method may miss some actual intermediary effects.

Author Contributions: S.Y., X.L. and J.R. conceptualized and designed the research. Y.L. and N.L. drafted the paper, acquired, and analyzed the data. J.F. and J.J. substantively revised the paper. All authors have read and agreed to the published version of the manuscript.

Funding: This study was supported by the Humanity and Social Science Youth Foundation of Ministry of Education in China (grant number: 20YJC790109) and School-level Scientific Research Project of Shenzhen Institute of Information Technology (grant number: SZIIT2020SK011).

Institutional Review Board Statement: Not applicable.

Informed Consent Statement: Not applicable.

Data Availability Statement: The data used in this paper come from the China Statistical Yearbook, China rural statistical yearbook, and China County Statistical Yearbook.

Conflicts of Interest: The authors declare that they have no known competing financial interest or personal relationship that could have appeared to influence the work reported in this paper.

\section{References}

1. Lovarelli, D.; Conti, C.; Finzi, A.; Bacenetti, J.; Guarino, M. Describing the trend of ammonia, participate matter and nitrogen oxides: The role of livestock activities in northern Italy during COVID-19 quarantine. Environ. Res. 2020, 191, 110048. [CrossRef]

2. Hellin, J.; McDonald, A.; Jat, M.L.; Shyamsundar, P.; Singh, A.K. Mitigating agriculture's contribution to air pollution in India. Lancet Planet. Health 2021, 5, e186. [CrossRef]

3. Zhao, H.; Zhang, X.; Zhang, S.; Chen, W.; Xiu, A.; Tong, D.Q. Effects of Agricultural Biomass Burning on Regional Haze in China: A Review. Atmosphere 2017, 8, 88. [CrossRef]

4. Zha, S.; Zhang, S.; Cheng, T.; Chen, J.; Huang, G.; Li, X.; Wang, Q. Agricultural Fires and their Potential Impacts on Regional Air Quality over China. Aerosol Air Qual. Res. 2013, 13, 992-1001. [CrossRef]

5. Long, X.; Luo, Y.; Sun, H.; Tian, G. Fertilizer using intensity and environmental efficiency for China's agriculture sector from 1997 to 2014. Nat. Hazards 2018, 92, 1573-1591. [CrossRef]

6. Wang, Y.; Lu, Y.; Yuan, J.; He, G. Evaluating the risks of nitrogen fertilizer-related grain production processes to ecosystem health in China. Resour. Conserv. Recycl. 2022, 177, 105982. [CrossRef]

7. Stacy, E.S. Effects of Environmental Regulation on Economic Activity and Pollution in Commercial Agriculture. B. E. J. Econ. Anal Policy 2009, 9. [CrossRef]

8. Huang, J.; Xiong, R.; Fang, L.; Li, T.; Shen, W. Estimation of interannual trends of ammonia emissions from agriculture in Jiangsu Province from 2000 to 2017. J. Atmos. Sci. 2020, 13, 268-273. [CrossRef]

9. Guo, Y.Z.; Qiao, W.F. Rural Migration and Urbanization in China: Historical Evolution and Coupling Pattern. Sustainability 2020, 12, 7307. [CrossRef]

10. Xu, D.D.; Guo, S.; Xie, F.; Liu, S.; Cao, S. The impact of rural laborer migration and household structure on household land use arrangements in mountainous areas of Sichuan Province, China. Habitat Int. 2017, 70, 72-80. [CrossRef]

11. Bhandari, P.; Ghimire, D. Rural Agricultural Change and Individual Out-migration. Rural Sociol. 2016, 4, 572-600. [CrossRef] [PubMed]

12. Tian, X.; Yi, F.J.; Yu, X.H. Rising cost of labor and transformations in grain production in China. China Agric. Econ. Rev. 2020, 1, 158-172. [CrossRef]

13. Luan, J. Does Agricultural Labor Migration Have Substitution Relation with Fertilizer Use? Experience and Evidence from China' s Main Provinces and Municipalities Planting Crops. J. Chongqing Technol. Bus. Univ. 2017, 4, 12-21. [CrossRef]

14. Barry, K.G.; Ashok, K.M. Farming Efficiency and the Determinants of Multiple Job Holding by Farm Operators. Am. J. Agric. Econ. 2004, 86, 722-729. [CrossRef]

15. Luan, J.; Li, T.T.; Ma, K. Study on the impact of labor transfer on the pollution of agricultural fertilizer sources in China. World Agric. 2016, 2, 63-69. [CrossRef]

16. Cheng, M.; Shi, Q.; Jin, Y.; Gai, Q. The income gap and its root causes: Model and empirical. Manage. World 2015, 7, 17-28. [CrossRef]

17. Carletto, C.; Savastano, S.; Zezza, A. Fact or artifact: The impact of measurement errors on the farm size-productivity relationship. J. Dev. Econ. 2013, 103, 254-261. [CrossRef]

18. Qiu, T.W. Will the non-farm transfer of rural labor reduce the rate of agricultural land output? J. Zhongnan Univ. Econ. Law 2018, 5, 151-160. [CrossRef] 
19. Gao, J.; Song, G.; Sun, X.Q. Does labor migration affect rural land transfer? Evidence from China. Land Use Pol. 2020, 99 , 105096. [CrossRef]

20. Zhong, F.N.; Lu, W.Y.; Xu, Z.G. Is it not conducive to food production for rural labor force to go out to work?-The analysis of the factor substitution and planting structural adjustment behavior and constraints of farmers. Chin. Rural Econ. 2016, 7, 36-47. Available online: http:/ / www.nssd.cn/articles/Article_Read.aspx?id=669630074 (accessed on 20 December 2021).

21. Wan, B.R. The current trend and suggestions of China's agricultural development. Iss. Agric. Econ. 2014, 4, 4-7. [CrossRef]

22. Chen, M.P.; Chen, J.N.; Lai, S.Y. Inventory analysis and spatial feature identification of agricultural and rural pollution in China. Zhongguo Huanjing Kexue 2006, 6, 751-755. [CrossRef]

23. Fan, B. Overall management and comprehensive management break through the difficult problem of rural water pollution control. Huanjing Baohu 2014, 15, 15-19. [CrossRef]

24. Cao, G.L.; Zhang, X.Y.; Wang, D.; Zheng, F.C. Inventory of Emissions of Pollutants from Open Burning Crop Residue in China. J. Agric. Environ. Sci. 2005, 24, 800-804. [CrossRef]

25. Wang, H.D.; Zhao, Z.Q.; Winiwarter, W.; Bai, Z.H.; Wang, X.; Fan, X.W.; Zhu, Z.P.; Hu, C.S.; Ma, L. Strategies to reduce ammonia emissions from livestock and their cost-benefit analysis: A case study of Sheyang county. Environ. Pollut. 2021, 290, 118045. [CrossRef]

26. Ministry of Ecological and Environment of P. R. China. Notice on Reduction and Exemption of Sewage Charges for Poultry Industry (Huanfa [2004] No.43). Available online: http:/ / www.mee.gov.cn/gkml/zj/wj/200910/t20091022_172271.htm (accessed on 25 December 2021).

27. Wen, Z.L.; Ye, B.J. Analyses of Mediating Effects: The Development of Methods and Models. Adv. Psychol. Sci. 2014, 22, 731-745. [CrossRef] 